\title{
Review: orlistat and sibutramine are modestly effective for weight loss at 1 year
}

Padwal R, Li SK, Lau DC. Long-term pharmacotherapy for obesity and overweight. Cochrane Database Syst Rev 2004;(3):CD004094.

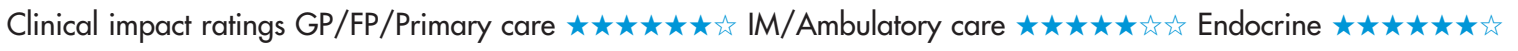

What is the effectiveness of anti-obesity medications in trials with $\geqslant 1$ year follow up?

METHODS

\begin{tabular}{|c|c|}
\hline$\square$ & $\begin{array}{l}\text { Data sources: Medline (1966 to December 2002), EMBASE/ } \\
\text { Excerpta Medica (1980 to December 2002), Cochrane } \\
\text { Controlled Trials Register (lssue 3, 2002), Current Controlled } \\
\text { Trials metaRegister of Controlled trials (December 2002), } \\
\text { bibliographies of relevant studies, and experts and } \\
\text { manufacturers. }\end{array}$ \\
\hline & $\begin{array}{l}\text { Study selection and assessment: randomised controlled trials } \\
\text { (RCTs) of approved anti-obesity agents for weight loss or weight } \\
\text { maintenance in adults with body mass index }(\mathrm{BMI}) \geqslant 30 \mathrm{~kg} / \mathrm{m}^{2} \text { or } \\
\geqslant 27 \mathrm{~kg} / \mathrm{m}^{2} \text { plus } \geqslant 1 \text { obesity related comorbid condition }(\mathrm{eg} \text {, } \\
\text { coronary artery disease, stroke, type } 2 \text { diabetes, heart failure, } \\
\text { dyslipidaemia, hypertension, reproductive or gastrointestinal } \\
\text { cancer, gallstones, fatty liver disease, osteoarthritis, and sleep } \\
\text { apnoea), had blinding of patients and healthcare providers, } \\
\text { included a placebo group or another anti-obesity drug group, } \\
\text { used an intention to treat analysis, and had } \geqslant 1 \text { year of follow up. } \\
\text { Studies of off-label therapy; drugs with high addiction potential } \\
\text { that preclude long term use; or investigational, herbal, or } \\
\text { alternative compounds were excluded. Study quality was } \\
\text { assessed. }\end{array}$ \\
\hline 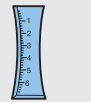 & Outcome: weight loss at 1 year. \\
\hline
\end{tabular}

\section{MAIN RESULTS}

Only trials of orlistat and sibutramine met the selection criteria. 16 RCTs ( 11 of orlistat and 5 of sibutramine) were included. 14 RCTs (11 of orlistat and 3 of sibutramine) were weight loss trials in which drug therapy was used in conjunction with a weight loss diet for 1 year. 2 RCTs of sibutramine were weight maintenance trials with 12 to 18 month follow up.

11 weight loss trials $(n=6021$, mean age $49 y, 71 \%$ women, mean BMI $35.7 \mathrm{~kg} / \mathrm{m}^{2}$ ) used standard doses of orlistat ( $120 \mathrm{mg}, 3$ times $/ \mathrm{d}$ ). 3 weight loss trials $(\mathrm{n}=929$, mean age $47 \mathrm{y}, 80 \%$ women, mean BMI $33.4 \mathrm{~kg} / \mathrm{m}^{2}$ ) used sibutramine, 10 to $20 \mathrm{mg} /$ day. Patients who received orlistat had a $2.7 \mathrm{~kg}$ ( $95 \%$ CI 2.3 to $3.1 \mathrm{~kg}$; 11 RCTs) greater weight loss $(2.9 \%$, CI 2.3 to $3.4 ; 10$ RCTs) than patients who received placebo, and sibutramine group patients had a $4.3 \mathrm{~kg}$ (CI 3.6 to $4.9 \mathrm{~kg}$;

For correspondence: Dr $\mathrm{R}$ Padwal, University of Alberta and Walter $\ddot{C}$ Mackenzie Health Sciences Centre, Edmonton, Alberta, Canada. rpadwal@ valberta.ca

Source of funding: no external funding.
3 RCTs) greater weight loss (4.6\%, CI 3.8 to $5.4 ; 3$ RCTs) than placebo group patients. More orlistat and sibutramine group patients achieved $5 \%$ and $10 \%$ weight losses than placebo group patients (table).

2 sibutramine weight maintenance trials $(\mathrm{n}=627$, mean age $49 \mathrm{y}$, $83 \%$ women, mean BMI $37 \mathrm{~kg} / \mathrm{m}^{2}$ ) used a $10 \mathrm{mg} /$ day dose of sibutramine. Results from these 2 trials were not pooled, but both showed greater weight loss in participants who received sibutramine than did those who received placebo.

\section{CONCLUSION}

Orlistat and sibutramine are modestly effective for weight loss at 1 year.

Abstract and commentary also appear in ACP Journal Club.

\section{Commentary - continued from previous page}

A Ithough orlistat and sibutramine undoubtedly produce weight loss, the effect is modest and is less than can be achieved with intensive lifestyle interventions. Combining increased physical activity and calorie restriction has been shown to reduce the risk of incident diabetes by as much as $58 \%$ in 2 similar studies. ${ }^{2}{ }^{3}$ Lifestyle interventions have been poorly studied but are the preferred treatment option for most individuals, although many persons who are overweight or obese are unable to undertake or adhere to intensive lifestyle interventions, especially over the longer term. Until effective methods of obesity prevention are introduced, a role for pharmacological treatment of obesity remains. Further research is required to establish cost effectiveness and to identify subgroups of patients who are most likely to benefit from different approaches to weight loss.

Christopher D Byrne, FRCP, FRCPath, PhD Southampton General Hospital Southampton, UK Sarah Wild, MRCP, MRCGP, MFPHM, PhD University of Edinburgh Edinburgh, UK

1 Torgerson JS, Hauptman J, Boldrin MN, et al. XENical in the prevention of diabetes in obese subjects (XENDOS) study: a randomized study of orlistat as an adjunct to lifestyle changes for the prevention of type 2 diabetes in obese patients. Diabetes Care 2004;27:155-61.

2 Tuomilehto J, Lindström J, Eriksson JG, et al. Prevention of type 2 diabetes mellitus by changes in lifestyle among subjects with impaired glucose tolerance. N Engl J Med 2001;344:1343-50.

3 Knowler WC, Barrett-Connor E, Fowler SE, et al. Reduction in the incidence of type 2 diabetes with lifestyle intervention or metformin. N Engl J Med 2002;346:393-403.

Orlistat (Orl) or sibutramine (Sib) $v$ placebo for weight loss at 1 year*

\begin{tabular}{|c|c|c|c|c|c|c|}
\hline \multirow[b]{2}{*}{ Outcomes } & \multirow[b]{2}{*}{ Number of trials } & \multicolumn{3}{|c|}{ Weighted event rates } & \multirow[b]{2}{*}{ RBI $(95 \% \mathrm{Cl})$} & \multirow[b]{2}{*}{ NNT (Cl) } \\
\hline & & Orl & Sib & Placebo & & \\
\hline \multirow[t]{2}{*}{$5 \%$ weight loss } & 11 & $52 \%$ & - & $31 \%$ & $75 \%$ (53 to 100$)$ & $5(5$ to 6$)$ \\
\hline & 3 & - & $49 \%$ & $15 \%$ & $256 \%$ (132 to 446$)$ & $3(3$ to 4$)$ \\
\hline \multirow[t]{2}{*}{$10 \%$ weight loss } & 10 & $25 \%$ & - & $13 \%$ & $93 \%$ (66 to 125$)$ & 9 (7 to 13$)$ \\
\hline & 3 & - & $20 \%$ & $5 \%$ & $345 \%$ (168 to 639$)$ & $7(4$ to 25$)$ \\
\hline
\end{tabular}

*Abbreviations defined in glossary; weighted event rates, RBI, NNT, and Cl calculated from data in article using a random effects model. 